\title{
УДК 378.015.31:004.738.1
}

\section{Наливайко Олексій}

Кандидат педагогічних наук, доцент кафедри педагогіки

Харківський національний університет імені В. Н. Каразіна, Харків, Україна

nalyvaiko@karazin.ua

ORCID: 0000-0002-7094-1047

\section{МОДЕЛЬ ПРОЕКТНОЇ ДІЯЛЬНОСТІ ЗДОБУВАЧІВ ОСВІТИ В ЦИФРОВОМУ ПРОСТОРІ НА ПРИКЛАДІ ДИСЦИПЛІН ПЕДАГОГІЧНОГО ЦИКЛУ}

\begin{abstract}
Анотація. У статті представлено модель проектної діяльності здобувачів вищої освіти в умовах дистанційно-цифрового навчання на прикладі дисциплін педагогічного циклу підготовки. Проведено аналіз науково-літературних джерел, присвячених різним аспектам проектної діяльності й особливо у цифровому освітньому просторі. Описано теоретичні положення проведення проектної діяльності у цифровому просторі та представлено завдання, які можуть виконувати здобувачі в рамках цієї діяльності. Висвітлено процес упровадження проектної діяльності в умовах вимушеного дистанційного навчання на прикладі студентів 2 курсу факультету іноземних мов Харківського національного університету імені В. Н. Каразіна у 2019/2020 навчальному році та закцентовано увагу на етапах створення й супроводу цієї діяльності з боку викладача та студента. До таких етапів віднесено: підготовчий (налагодження зв'язку між здобувачами та викладачем), операційний (створення проекту), корекційний (внесення змін та доповнень) i завершальний (публічний захист та оформлення результатів). У розділі обговорення розкрито перспективи та ризики впровадження проектної діяльності у цифровому освітньому середовищі. У висновках надано рекомендації щодо ефективної організації проектної діяльності в цифровому освітньому просторі на прикладі дисциплін педагогічного циклу підготовки: попередня підготовча робота викладача щодо роз'яснення вимог, які висуваються при вивченні курсу та організації проектної діяльності (акцент тут робиться на старост груп через велику кількість здобувачів: у середньому 230 осіб); яскраве представлення вимог та попередніх здобутків щодо створення творчих робіт (проектів); визначення чіткої послідовності дій цього процесу; роз'яснення послідовності дій та комунікації між учасниками процесу викладач-студент, викладач-група студентів, студентстудент; підтримка зворотного зв'язку на консультаціях, у месенджерах (з акцентом на зручність для усіх сторін); поточна перевірка отриманих результатів, тобто підтримка та корекція проектних робіт 3 обов'язковим роз'ясненням проблемних моментів для здобувачів; організація публічних захистів творчих робіт (проектів) на перевірених платформах цифрової комунікації; дотримання принципів академічної доброчесності в умовах дистанційно-цифрового навчання через перевірку робіт у загальновизнаних програмах перевірки цифрової інформації; виділення часу під окремі консультації для науково-дослідних проектів як таких, які потребують особливої уваги через свою складність; застосування хмарних сервісів фіксації результатів успішності здобувачів тощо.
\end{abstract}

Ключові слова: викладач, дистанційне навчання, проектна діяльність, студенти, творчі проекти, цифрові засоби навчання

Вступ. Швидка трансформація освітньої дійсності, яка відбувається в контексті збільшення ваги інформаційно-цифрових технологій значно пожвавилася через введення карантинних обмежень, викликаних пандемією COVID-19. Світова освітня спільнота у своїй більшості не була готова до настільки швидкого переходу до змішаної, а інколи й повністю дистанційної системи взаємодії між учасниками освітнього процесу. Особливо цей процес болюче проходив у закладах вищої освіти України. Більшість українських ЗВО не мали настільки розвиненої системи взаємодії у цифровому форматі між викладачами та студентами, щоб забезпечити безболісний перехід до масового використання цифрових засобів навчання та комунікації [1, с. 8384]. Проте не можна сказати, що освітній процес зупинився, адже функціонування у сучасному світі майже не можливе без постійного використання цифрових засобів комунікації та взаємодії. Важливо підкреслити, що сучасні здобувачі освіти, особливо 
ті, що навчаються на 2-3 курсах 3ВО, на момент введення карантинних обмежень (березень 2020 року) народилися та жили все своє життя до пандемії, проводячи значний час у цифровому середовищі, тому для них перехід у цифровий формат навчання пройшов менш напружено 3 точки зору використання цифрових засобів навчання та інших платформ взаємодії та зв'язку. 3 іншої сторони відсутність чітких методичних вказівок та рекомендацій [2, с. 144] значно загальмувала надання якісних освітніх послуг та підвищила негативні явища, які супроводжують процес зміни сталих моделей поведінки та взаємодії. До них можна віднести: тривожність та занепокоєння за майбутні результати, власний майбутній професійний рівень, збільшення проявів академічної недоброчесності та відсутність особистого контакту між учасниками освітнього процесу.

Наявність цих проблем зумовлює пошук простих та ефективних шляхів взаємодії в освітньому процесі ЗВО на засадах колективної діяльності, взаємної зацікавленості та унікальності створюваного освітнього контенту. Дієвим шляхом вирішення цих проблем може стати проектна діяльність у цифровому середовищі. Проте задля врегулювання розбіжностей та некоректного розуміння цього процесу потрібно визначити чітку модель імплементації проектної діяльності в освітньому процесі здобувачів, які вивчають дисципліни педагогічного циклу.

Аналіз останніх досліджень і публікацій. Використання проектної технології в освітній діяльності має значну історію та багато шляхів реалізації. Так питанням теоретичних основ упровадження проектної технології займалися Barron, B. J., Schwartz D. L., Vye N. J., Moore A., Petrosino A., Zech L., \& Bransford J. D. [3], Blumenfeld P. C., Soloway E., Marx R. W., Krajcik J. S., Guzdial M., \& Palincsar A. [4], Gary K. [5], Scarbrough H., Swan J., Laurent S., Bresnen M., Edelman L., \& Newell S. [6]; забезпечення колективної взаємодії вивчали в умовах проектної діяльності Bagheri M., Ali W. Z. W., Abdullah M. C. B., \& Daud S. M. [7], Barak M., \& Raz E. [8], Hung C. M., Hwang G. J., \& Huang I. [9], Lee H. J. [10]; застосування цифрових засобів навчання у проектній діяльності досліджували Жерновникова О. А., Перетяга Л. Є., Ковтун А. В., Кордубан M. В., Наливайко О. О., \& Наливайко Н. А. [11], Amhag L., Hellström L., \& Stigmar M. [12], Ardaiz-Villanueva O., Nicuesa-Chacón X., Brene-Artazcoz O., de Acedo Lizarraga M. L. S., \& de Acedo Baquedano M. T. S. [13], Moursund D. [14]; організацію навчального процесу на засадах проектної діяльності вивчали Bell S. [15], Miglino O., \& Walker R. [16], Raat J. H., \& de Vries M. [17]; зв'язок проектної діяльності та цифрового середовища висвітлювали у своїх працях Barreda S. V. [18], Boss S., \& Krauss J. [19], Claro M., Salinas Á., Cabello-Hutt T., San Martín E., Preiss D. D., Valenzuela S., \& Jara I. [20], Ferreira V. G., \& Canedo E. D. [21], Gómez-Pablos V. B., del Pozo M. M., \& MuñozRepiso A. G. V. [22].

Мета статті: розробка ефективної моделі проектної діяльності здобувачів освіту у цифровому просторі на прикладі дисциплін педагогічного циклу.

Завдання дослідження:

- теоретичне висвітлення існуючих протиріч у організації проектної діяльності в цифровому середовищі;

- розробка власної моделі проектної діяльності у цифровому освітньому середовищі;

- надання рекомендацій щодо вдосконалення існуючого досвіду проектної діяльності в умовах карантинних обмежень та цифрового освітнього середовища.

Теоретичні положення дослідження. Проектна діяльність учасників освітнього процесу у ЗВО є невід'ємною складовою ефективної побудови передачі та засвоєння знань здобувачами. Уміння правильно та ефективно організувати таку діяльність 
студентів завжди дуже цінувалося серед освітньої спільноти та самих здобувачів. Часи словесно-ілюстративної передачі знань доживають свої останні моменти і це $\epsilon$ об'єктивним процесом трансформації освітнього процесу не лише в Україні, а й і у всьому світі. Не секрет, що сучасне покоління здобувачів має найбільший доступ до інформації за увесь час існування людства. Долучаючись до цифрових засобів 3 найменшого віку, здобувачі відкривають для себе неспинний потік інформації, яку вони споживають, тому викладач, який хоче привернути увагу своїх здобувачів, має використовувати сучасні методи активізації уваги та взаємодії в освітньому процесі на засадах активних та інтерактивних педагогічних методів, засобів та технологій. Тобто викладач, який не опановує сучасні підходи щодо організації освітнього процесу та не враховує об'єктивні якості сьогоднішніх здобувачів ризикує залишитися на «узбіччі» своєї професії. І навпаки, викладачі, які прагнуть до підвищення свого авторитету серед здобувачів, повинні своєчасно пристосовуватися до нагальних змін у суспільних відносинах, частиною яких є освіта.

Вимушений перехід освітнього процесу в цифровий формат висвітив існуючі проблеми та протиріччя нашої освіти, до яких можна віднести:

- застарілу нормативно-правову базу регулювання освітніх відносин у цифровому форматі;

- відсутність чіткої політики держави щодо забезпечення цифровізації освітнього середовища на всіх освітніх ланках;

- застарілість підходів у навчанні майбутніх педагогів та підтримуючого персоналу;

- пасіонарність більшості адміністрації ЗВО (і не завжди вона направлена на удосконалення освітнього процесу, особливо у цифровому середовищі);

- небажання деяких науково-педагогічних працівників 3ВО оволодіти цифровими засобами навчання на належному рівні;

- декларативність заяв владних ланок та неможливість реалізації цих заяв у наявній педагогічній практиці (значно понижує мотивацію до якісної роботи та взаємодії);

- збільшення проявів академічної недоброчесності серед здобувачів та закривання на це очей викладачів через неможливість показати цю роботу у своїх звітах та нормах відпрацювання часу;

- «цифровий розрив» між містом та селом.

Вирішення цих проблем та протиріч $є$ одним 3 магістральних напрямків у розбудові ефективного освітнього середовища, яке може приймати та завчасно вирішувати виклики, що виникають у сучасному вирі суспільних відносин та потрясінь.

Застосування проектної технології у цифровому форматі навчання передбачає наявність варіативності та права вибору у здобувачів відповідно до основних дидактичних принципів побудови ефективного освітнього середовища. Підкреслимо, що викладання протягом 5 навчальних років здобувачам факультету іноземних мов ХНУ імені В. Н. Каразіна дозволили виробити прийнятний для всіх учасників формат проведення проектної діяльності. Тобто ця модель дозволяє виконувати проектні роботи як у традиційному навчанні, так і в умовах переходу до цифрового освітнього простору.

Опис видів творчих робіт (проектів) за вибором з курсу «Педагогіка»: $1 *$. Дослідження проблем та перспектив упровадження цифрових технологій в освітній процес освітніх закладів України або інших країн.

Наприклад, це може бути проект, спрямований на створення сайту з методичними рекомендаціями для майбутніх педагогів (студентів) або молодих викладачів у галузі 
педагогічної діяльності. Також це можуть бути ігри або веб-квести, створені за допомогою мобільних або комп'ютерних засобів. 3 подальшою презентацією отриманих результатів.

$2 *$. Розробка «Форсайт проектів» 3 педагогіки.

Наприклад, використання методу «Дельфі» для визначення перспектив розвитку освіти та педагогіки в найближчі 5-10 років (у форматі факультету, кількох факультетів або університету).

\section{3. Дидактична гра за вибором студентів з будь-яких тем курсу «Педагогіка».}

Гра може бути створена за аналогією гри «Лото», де завдання у вигляді питань записані на картках (або у цифровому форматі). Ці ж завдання можуть бути введені на екран за допомогою слайдів (по типу гри «Що? Де? Коли?»). Ситуації, завдання і питання для настільних ігор можуть мати музичний супровід. Також можуть використовуватися мобільні додатки, такі як «Stop Motion», «Kahoot», Quizizz, Actively Learn тощо.

\section{1. Презентація ігрової ситуації.}

Всі ситуації умовно розділені на три групи:

- адаптація до колективу здобувачів;

- адаптація до колективу педагогів;

- адаптація до внутрішньо-освітнього управління.

\section{План складання:}

Опис ситуації (вона може бути взята 3 досвіду або бути змодельована Вами) текстовий опис, слайд.

1. Постановка проблемного питання (питання, що не має однозначного вирішення, що виводить на дискусію) - текстовий опис, слайд.

2. Вказівка рольових позицій (команд) - слайд.

3. Можливі стратегії кожної з команд (вказати, яку ідею вони захищають; можливі «+» і «-» даної стратегіï) - текстовий опис, слайд.

4. Ваше бачення даного проблемного питання (з чим із запропонованих стратегій згодні, а з чим ні).

Настільні ігри та презентації ігрових ситуацій можуть супроводжуватися нарізкою кадрів з художніх та мультиплікаційних фільмів.

4. Розробка презентації або відео-ролика 3 питань, пов'язаних 3 порівнянням освітніх систем різних країн.

У презентації потрібно показати відмінні або спільні риси освітніх систем на прикладі конкретного навчального закладу або системи (школа, 3ВО) навчання окремої країни. Тобто, дати визначення, що таке «освітня система» і як воно реалізується в шкільній системі та ЗВО України або інших країн (кількість слайдів 20-25, ролик до 5-7 хвилин). У кінці презентації або відео-ролика потрібно вказати список джерел, які використовувалися при виконанні проекту.

5. Фільм-дискусія (на прикладі творчості будь-якого педагога, наприклад: «Ідеї А. С. Макаренка в сучасній освіті та студентському житті»).

Фільм має включати посилання на ідеї або досвід визначних педагогів у контексті сучасних проблем або перспектив розвитку освітньої діяльності.

\section{6*. Соціально-педагогічне дослідження.}

Вибрати актуальну проблему, пов'язану 3 питаннями курсу «Педагогіка» (наприклад, «Дидактика», «Процес виховання», «Загальні засади педагогіки»), і провести дослідження на обрану тему.

Дослідження включає:

1. Актуальність проблеми дослідження.

2. Мета дослідження. 
3. Проведення експериментальної частини.

4. Результати дослідження, які подаються у вигляді таблиць, схем, діаграм на основі проведеного експерименту (презентація).

5. Висновки.

7*. Створення й опис кейсів (педагогічних ситуацій і шляхів їх вирішення).

1. Створити 5 кейсів-ситуацій (3 про школу та 2 про університет).

2. Описати проблемну ситуацію.

3. Змоделювати загальну перспективу розвитку проблемної ситуації.

4. Представити правильний варіант вирішення ситуації з обгрунтуванням.

5. Створити презентацію по 3 слайди на одну кейс-ситуацію (1 слайд на обгрунтування проблеми +1 слайд на вирішення +1 слайд на висновки).

8*. Свій унікальний проект 3 педагогіки! Творчість без кордонів (але в межах пристойності!).

*Бали за даний проект збільшуються, якщо це подано у форматі відео-ролику.

Важливо зазначити, що наявність варіативності значно підвищує креативність здобувачів. Опитування, які проводяться після закінчення курсу «Педагогіка» протягом 4 навчальних циклів починаючи 3 2016/2017 навчального року, показують значну зацікавленість саме у різноманітності завдань та можливості створити власний унікальний контент для освітньої діяльності.

Особливу увагу здобувачів спрямовуємо на те, що кожен із видів творчих робіт (проектів) повинен мати короткий опис використаних комп'ютерних або мобільних програм при його створенні (від 2 до 5 сторінок)

\section{Сценарій опису результатів творчої роботи включас:}

1. Актуальність роботи (Чому ця робота важлива? Чому Ви обрали цю тему?).

2. Виклад основного матеріалу (розкрити механізм створення проекту та технічні засоби та програми, які використовувалися в процесі його створення, монтажу тощо).

3. Висновки та перспективи (головні результати та перспективи застосування в освітньому процесі).

Результати. Модель упровадження проектної діяльності здобувачів у рамках вивчення дисциплін педагогічного циклу показала значні результати у покращенні мотивації до навчання та підвищення працездатності здобувачів. Зазначимо, що виконання проектної діяльності у цифровому та традиційному форматах показує високі показники задіяності студентів у навчальний процес. Так, при медіанній кількості студентів, які навчаються на другому курсі факультету іноземних мов ХНУ імені В. Н. Каразіна, а це приблизно 230 осіб щороку, кількість здобувачів, які приймають участь у проектній діяльності становить приблизно 190-200 осіб (зазначимо, що виконання або не виконання проектних завдань $є$ вибором самих студентів, про що викладач публічно заявляє на початку курсу).

Розглянемо більш детально алгоритм організації проектної діяльності здобувачів 2-го курсу факультету іноземних мов ХНУ імені В.Н. Каразіна у 2019/2020 навчальному році в умовах вимушеного дистанційного навчання.

Викладання педагогічних дисциплін на другому курсі починається у весняному семестрі (лютий-червень) та включає 3 кредити для засвоєння, аудиторна робота складає 32 години для кожної групи (у 2020 році їх налічилося 18 академічних груп), 3 яких 16 годин - це лекційні заняття і 16 годин - семінарські, дисципліна закінчується чотирьохрівневим контролем (екзаменом). Відзначимо, що на самостійну роботу здобувачі мають 58 години за курсом «Педагогіка», що зумовлює пошук змістовних та цікавих робіт творчого характеру. 
Модель освітньої взаємодії у проектній діяльності грунтується на таких засадах як: первина організація, поточний контроль успішності, публічний захист та представлення результатів, оформлення отриманих результатів у цифровий контент. Розглянемо більше детально цей процес. На першій лекції викладач ознайомлює здобувачів 3 системою оцінювання та зазначає, що за «творчу роботу» здобувачі зможуть максимально отримати 20 балів, що складає 1/5 від їх загальної кількості балів (див. Рис. 1.). Підкреслимо, що через велику кількість здобувачів доцільно провести підготовчу роботу у рамках організації взаємодії між викладачем та здобувачами у цифровому просторі. Найбільш дієвим на наш погляд є створення груп у цифровому месенджері «Telegram», цей цифровий додаток зв’язку та обміну контентом займає домінуюче положення у зв'язку між здобувачами, тому рекомендуємо використовувати саме його. Знайомство зі старостами та попереднє роз'яснення правил і критерії оцінки дозволяє значно підвищити комунікацію зі студентами групи у майбутньому. Іншим важливим аспектом ефективного виконання проектної роботи $\epsilon$ чітке визначення дедлайнів надсилання робіт та їх перевірки на доброчесність.

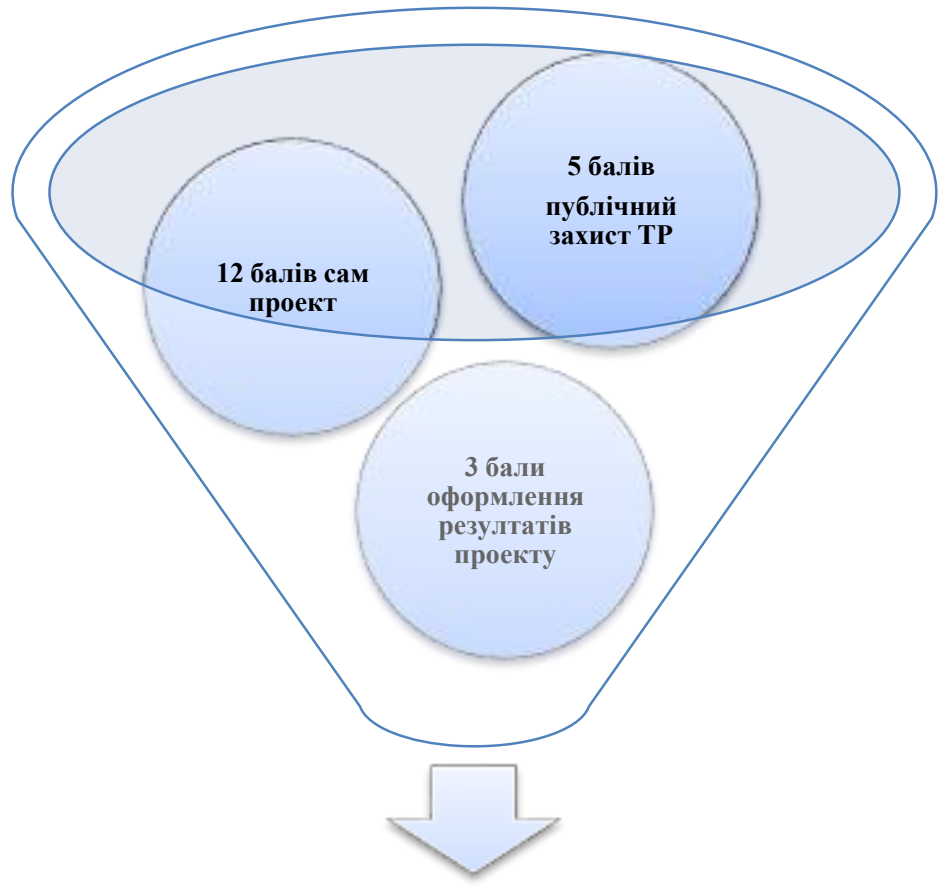

Рис.1. Розподіл балів за творчу роботу (загальна оцінка 20 балів)

Наступний крок включає представлення тем творчих робіт та прикладів вже створених робіт здобувачами попередніх років. 3 прикладами студенти можуть ознайомитися за посиланням на ютуб канал «Творча педагогіка у цифровому просторі» (див. Рис. 2) (https://www.youtube.com/channel/UCIwOqrMR3X1GRLQANSmiItA). 


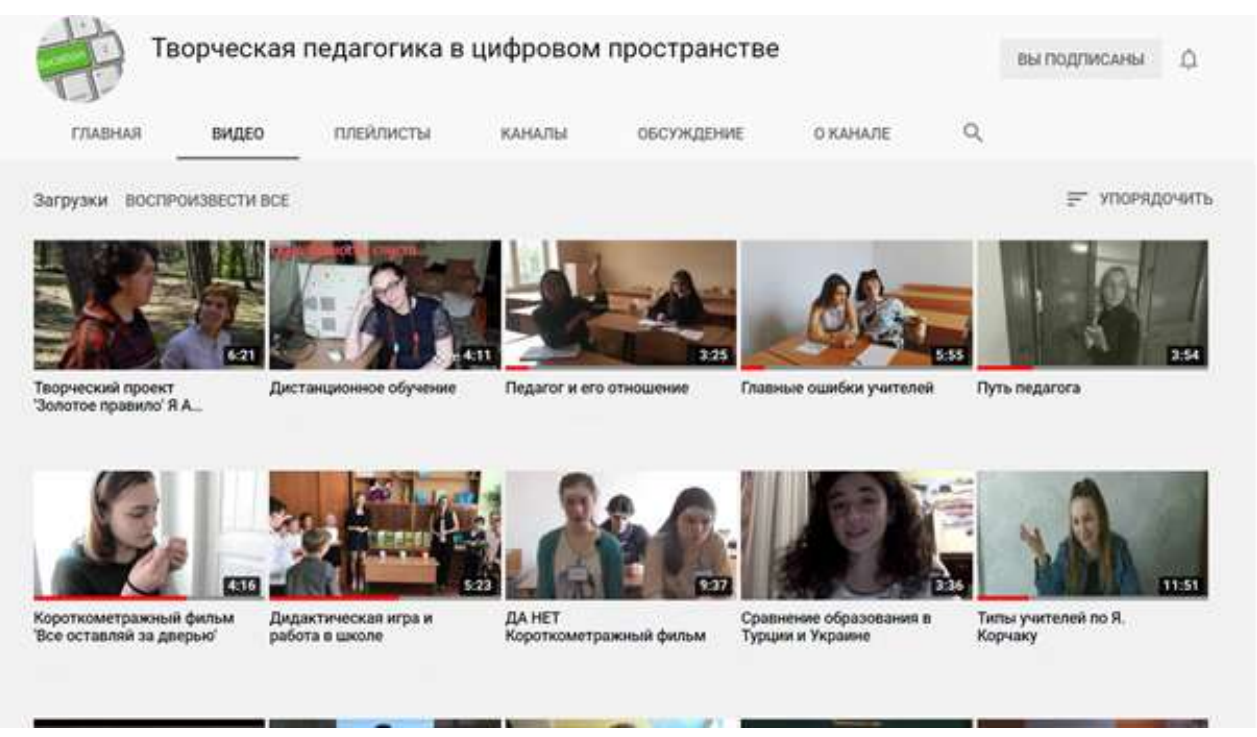

Рис 2. Ютуб канал «Творча педагогіка у цифровому просторі»

Підкреслимо, що проекти попередніх років можна використовувати у процесі проведенням занять, особливо лекційного формату, для перегрупування уваги здобувачів на інший вид діяльності.

У подальшому потрібно чітко визначити проведення консультацій для здобувачів, які виявили бажання приймати участь у проектній діяльності. Введення карантинних обмежень негативно вплинуло на комунікацію між здобувачами, тому наявність ще одного майданчика для їх взаємодії $€$ важливим фактором підтримки студентів у незнайомих для них умовах.

Розвиваючи думку щодо покращення комунікації та взаємодії між здобувачами, викладач як правило рекомендує об'єднуватися у проектні групи до 5 осіб не залежно від академічної приналежності до навчальної групи. Таких підхід дозволяє підвищити варіативність та розвити зв'язок і порозуміння між студентами. Проте можливі варіанти, де здобувачі виконують проектну роботу індивідуально.

Особливе місце в системі проектної діяльності у цифрову форматі займає наукодослідницька діяльність здобувачів. Перед початком курсу викладач, проводячи підготовчу роботу, може обрати академічні групи з найвищою успішністю серед всього потоку курсу. Як правило це 3-4 групи, яким надається можливість провести проектну роботу у форматі актуальної теми сучасного наукового пошуку. У цьому разі викладач повинен виявити особливу увагу та доброчесність по відношенню до здобувачів, тобто надати можливість прийняти у цій роботі участь усій групі (наприклад, у 2019/2020 навчальному році середня кількість учасників у таких групах була 12 здобувачів). Така кількість учасників обумовлена складністю проведення проектної діяльності у форматі дослідження та обробки результатів. Наприклад, проведення форсайт-дослідження [1, с. 82] потребує великої уваги та кількості учасників для обробки отриманої інформації. Оцінювання результатів проведеного дослідження відбувається в окремий день та включає заплановані дебати між представниками різних проектних груп дослідників, що значно збільшує час захисту робіт. Особливо цінною цей вид діяльності здобувачів робить їх подальший науковий пошук. Як правило найбільш ініціативні студенти 3 проектної групи у наступному навчальному році виказують бажання проводити дослідження вже у форматі більш грунтовних наукових розвідок та публікацій результатів у провідних фахових виданнях України та світу. 
Публічний захист творчих робіт включає в себе ряд особливостей, які викликані введенням карантинних обмежень.

По-перше. У другій третині курсу (на прикладі 2019/2020 навчального року це друга половина квітня) здобувачі вже знаходяться на фінішній прямій створення своїх проектних робіт і вже точно знають з ким вони співпрацюють. Тобто вони вже можуть записуватися на захист робіт. Цей процес включає створення викладачем Google документу у форматі таблиці, де здобувачі 3 попередньо створеннях групових електронних адрес можуть реєструватися (функціонал Google документів дозволяє відстежувати активність та зміни у цьому форматі, що збільшує відповідальність студентів).

По-друге. Після закінчення процедури реєстрації, яка, як правило, не перевищує одного тижня, створюється інший Google документ з розкладом захистів, де студенти у демократичній та вільній формі обирають з наявних проміжків часу зручний для своєї групи або для себе (якщо вони створюють проект індивідуально) час захисту роботи.

По-третє. Викладач забезпечує організаційні моменти проведення захисту, тобто обирає зручну та зрозумілу платформу. У зазначений вище період це була платформа ZOOM. Також перевіряє технічні можливості та якість контенту, який надсилають студенти. Це важливий етап, тому що здобувачі дуже стурбовані можливими технічними проблемами і такий стрес негативно впливає на якість захисту. Крім того, обізнаність викладача з сучасними засобами цифрового зв'язку значно підвищує його авторитет в очах здобувачів і показуе приклад організації важливих заходів у невизначених умовах.

По-четверте. Захист проходить у форматі демонстрації проектних здобутків студентів. На один виступ відводиться до 10 хвилин та надається 5 хвилин для обговорення серед студентів, які присутні на захисті. Важливо відзначити, що для більшої відкритості учасників цього процесу бажано провести загальнокурсову консультацію, де у зрозумілій формі, а ще краще під запис (функціонал ZOOM та інших платформ зв'язку це дозволяе) роз'яснити формат та обов'язки сторін у цьому процесі та за необхідності надати доступ до повторного перегляду організаційної інформації.

По-п'яте. Студенти можуть ознайомитися 3 загальними результатами своєї проектної діяльності в онлайн форматі через доступ до загальної таблиці результатів за курсом, що розміщено у хмарному сховищі сервісів Google (на початку курсу здобувачі мають можливість відслідковувати свої результати через доступ до Google документу, оформленого у таблиці, де один із стовпчиків відображає успішність проектної роботи студентів).

Таким чином, дотримання системності та послідовності у роботі зі здобувачами дозволяє максимально зменшити ризики непорозуміння та технічних негараздів, які дуже часто трапляються у такому процесі. Наприклад, через відсутність у багатьох здобувачів професійної техніки запису відео або звуку, трапляються випадки, коли відео ряд не чутно або відео записано у форматі, який не підтримується. У таких випадках і потрібна попередня робота щодо виявлення та усунення таких проблем.

Побудова моделі успішної проектної діяльності у цифровому освітньому просторі включає такі етапи: підготовчий (налагодження зв'язку між здобувачами та викладачем), операційний (створення проекту), корекційний (внесення змін та доповнень) і завершальний (публічний захист та оформлення результатів).

Одним із найважливіших завдань упровадження проектної діяльності здобувачів освіти у цифровому просторі поряд з розвитком «м'яких навичок» та підвищенням взаємодії є розвиток цифрової компетентності. Без сформованих здатностей роботи у навчанні в цифрову просторі дуже важко уявити ефективне виконання вищезазначених 
проектних робіт. Крім того, важливо зробити акцент на тому, що цифрові засоби комунікації можна використовувати у навчальному процесі. Наприклад, звичайний смартфон можна використати для створення фільму у форматі Stop Motion [23, с.19], що значно пожвавить освітній процес та надасть можливість інтерактивної взаємодії.

\section{Обговорення}

Модель проектної діяльності здобувачів освіти у цифровому просторі має величезний потенціал для творчої реалізації та розвитку студентів у різних умовах організації освітнього процесу. Досить часто можна почути думку студентів, що їм не вистачає завдань творчого характеру, особливо на дисциплінах загального циклу підготовки. Розвиток творчого потенціалу здобувачів ЗВО має величезний горизонт впровадження у подальше професійне та особистісне зростання в умовах суспільної невизначеності. Розуміння та представлення у вигляді творчих проектів сучасних викликів, які спіткають освітню систему нашої країни, може надати у майбутньому великі можливості щодо власної реалізації й підвищення емоційного інтелекту та розвитку «м'яких навичок». Набуття навичок колективної взаємодії та наукового пошуку, які організовані на засадах академічної доброчесності, позитивно впливає на подальше навчання майбутніх фахівців. Проте проектна діяльність не є панацеєю від усіх проблем вимушеного або спеціально організованого навчання у цифровому просторі. Попередні дослідження показали [2, с. 155-156], що переведення навчання у цифровий простір збільшує спокусу серед учасників освітнього процесу щодо недотримання принципів академічної доброчесності у поточній та підсумковій навчальній діяльності. Упровадження проектної роботи, яка у своїй основі має творче спрямування та направлена на розвиток важливих компетентностей здобувачів, вбачається одним з дієвих способів організації освітньої взаємодії між викладачем та студентами.

Невирішеними залишаються питання системності впровадження проектної діяльності серед здобувачів освіти. Тобто зацікавлення цим видом набуття важливих професійних та особистісних компетентностей, наприклад, на другом курсі, не гарантує впровадження цього підходу на наступних курсах підготовки здобувачів, що негативно впливає на створені зв'язки та прагнення здобувачів. Зазначимо, що систематичність у цьому питанні має неменшу вагу ніж бажання та можливості учасників освітнього процесу (викладач-студент, студент-студент). Проте ми цілком розуміємо, що тотальне введення проектної діяльності може мати і негативні результати. Ми припускаємо, що деякі предмети непідлаштовані до проектної діяльності у цифровому просторі, і це нормально. Зазначимо, що на наш погляд освіта краще за все передається «повітрянокрапельним шляхом», адже дуже важко для усіх учасників освітнього процесу прийняти нові виклики і часто ми можемо бачити лише формальну взаємодію у навчанні між викладачем та студентом. Наприклад, якщо під час заняття або консультації здобувачі або викладач вимикає камеру свого пристрою і ми можемо спостерігати ситуацію, коли один «чорний екран» намагається донести інформацію до іншого «чорного екрану», а це на наш погляд руйнує одну з найважливіших частин надання якісної освіти - емоційне занурення учасників освітнього процесу. Підкреслимо, що ми обізнані з випадками, коли студенти або викладачі не мають можливості підключити відео через слабкий Інтернет зв'язок або присутність інших осіб у приміщенні тощо.

Сприйняття нового матеріалу, хочемо ми цього чи не хочемо, має більший позитивний ефект, якщо встановлюється позитивний емоційний зв'язок. А це дуже важко зробити за відсутності хоча б зорового контакту. Тому викладачам, які хочуть ефективно впроваджувати проектну діяльність у цифровому освітньому середовищі 
потрібно чітко розуміти свої можливості, прагнення та можливості здобувачів ЗВО та матеріально-технічне забезпечення цієї діяльності.

Висновки. Таким чином, проведене дослідження показує дієву модель побудови проектної діяльності здобувачів у цифровому просторі, як в умовах традиційного навчання, так і інших формах та способах освітньої взаємодії.

Найбільш цінними рекомендаціями щодо організації проектної діяльності у цифровому просторі $є$ :

- попередня підготовча робота викладача щодо роз'яснення вимог, які висуваються при вивченні курсу та організації проектної діяльності (акцент тут робиться на старост груп через велику кількість здобувачів, у середньому 230 осіб);

- яскраве представлення вимог та попередніх здобутків щодо створення творчих робіт (проектів);

- визначення чіткої послідовності дій цього процесу. Надання тем, вибір тем, самостійна організація творчих колективів відповідно до заявлених вимог, створення проекту, його перевірка, публічний захист, оформлення результатів;

- роз'яснення послідовності дій та комунікації між учасниками процесу: викладач-студент, викладач-група студентів, студент-студент. Підтримка зворотного зв'язку на консультаціях та у месенджерах (з акцентом на зручність для обох сторін);

- поточна перевірка отриманих результатів, тобто підтримка та корекція проектних робіт з обов'язковим роз'ясненням проблемних моментів для здобувачів;

- організація публічних захистів творчих робіт (проектів) на перевірених платформах цифрової комунікації;

- дотримання принципів академічної доброчесності в умовах дистанційноцифрового навчання через перевірку робіт у загальновизнаних програмах перевірки цифрової інформації;

- виділення часу під окремі консультації для науково-дослідних проектів як таких, які потребують особливої уваги через свою складність;

- застосування хмарних сервісів фіксації результатів успішності здобувачів тощо.

Проведене дослідження не вичерпує усіх аспектів проектної діяльності у цифровому просторі, тому що технологічний апарат освітніх сервісів та платформ стрімко розвивається і надає безліч способів упровадження в освітні й процес проектної роботи. Але основа взаємодії та організації цього процесу залишається незміною і направлена на розвиток цифрових навичок, командної взаємодії та допомоги, а також якісного представлення отриманих результатів.

У подальших наукових розвідках планується завершити та представити результати дослідження впливу проектно-цифрової діяльності здобувачів на формування їх цифрової компетентності.

\section{СПИСОК ВИКОРИСТАНИХ ДЖЕРЕЛ}

1. Nalyvaiko O., Adzhva D., \& Sarhsian E. Distance Education in V.N. Karazin Kharkiv National University in 2030, Students' View. Electronic Scientific Professional Journal "Open Educational e-Environment of Modern University". 2020. № 9. P. 7994. URL: https://doi.org/10.28925/2414-0325.2020.9.7

2. Наливайко О., Калістова О., Поляков Д. Дотримання академічної доброчесності навчальних досягнень здобувачів освіти в процесі дистанційного навчання. 
Освітологічний дискурс. 2020. №31(4). С. 143-162. URL: https://doi.org/10.28925/2312-5829.2020.4.10

3. Barron B. J., Schwartz D. L., Vye N. J., Moore A., Petrosino A., Zech L., \& Bransford J. D. Doing with understanding: Lessons from research on problem-and project-based learning. Journal of the learning sciences. 1998. № 7(3-4). P. 271-311.

4. Blumenfeld P. C., Soloway E., Marx R. W., Krajcik J. S., Guzdial M., \& Palincsar A. Motivating project-based learning: Sustaining the doing, supporting the learning. Educational psychologist. 1991. № 26(3-4). P. 369-398.

5. Gary K. Project-Based Learning. in Computer. 2015. vol. 48(9). pp. 98-100, doi: 10.1109/MC.2015.268.

6. Scarbrough H., Swan J., Laurent S., Bresnen M., Edelman L., \& Newell S. Projectbased learning and the role of learning boundaries. Organization studies. 2004. № 25(9). P. 1579-1600.

7. Bagheri M., Ali W. Z. W., Abdullah M. C. B., \& Daud S. M. Effects of project-based learning strategy on self-directed learning skills of educational technology students. Contemporary educational technology. 2013. № 4(1). P. 15-29.

8. Barak, M., \& Raz, E. Hot-air balloons: Project-centered study as a bridge between science and technology education. Science Education. 2000. № 84(1). P. 27-42.

9. Hung C. M., Hwang G. J., \& Huang I. A project-based digital storytelling approach for improving students' learning motivation, problem-solving competence and learning achievement. Journal of Educational Technology \& Society. 2012. № 15(4). P. 368379.

10. Lee H. J. Peer evaluation in blended team project-based learning; what do students find important? In E-Learn: World Conference on E-Learning in Corporate, Government, Healthcare, and Higher Education. (2009, October). P. 2838-2842. Association for the Advancement of Computing in Education (AACE).

11. Жерновникова О. А., Перетяга Л. Є., Ковтун А. В., Кордубан М. В., Наливайко О. О., Наливайко H. А. Технологія формування цифрової компетентності майбутніх учителів засобами гейміфікації. Інформаційні технології і засоби навчання. 2020. № 75(1). С. 170-185. https://doi.org/10.33407/itlt.v75i1.3036

12. Amhag L., Hellström L., \& Stigmar M. Teacher educators' use of digital tools and needs for digital competence in higher education. Journal of Digital Learning in Teacher Education. 2019. № 35(4). C. 203-220.

13. Ardaiz-Villanueva, O., Nicuesa-Chacón, X., Brene-Artazcoz, O., de Acedo Lizarraga, M. L. S., de Acedo Baquedano, M. T. S. Evaluation of computer tools for idea generation and team formation in project-based learning. Computers \& Education. 2011. № 56(3). P. 700-711.

14. Moursund D. Project-based learning using information technology. Eugene, OR: International Society for Technology in Education. 1999. $157 \mathrm{p}$

15. Bell S. Project-based learning for the 21st century: Skills for the future. The clearing house. 2010. № 83(2). P. 39-43.

16. Miglino O., \& Walker R. Teaching to teach with technology-a project to encourage take-up of advanced technology in education. Procedia-Social and Behavioral $\begin{array}{llllll}\text { Sciences. } & 2010 . & \text { № } & 2(2) . & \text { P. } & \text { 2492-2496. URL: }\end{array}$ https://doi.org/10.1016/j.sbspro.2010.03.359

17. Raat J. H., \& de Vries M. Technology in education: Research and development in the project 'Physics and Technology'. International Journal of Science Education. 1987. № 9(2). P. 159-168. 
18. Barreda S. V. Analysis of project based learning in a digital environment at a networked high school. JETT. 2016. № 7. P. 27-49.

19. Boss S., Krauss J. Reinventing project-based learning: Your field guide to real-world projects in the digital age. International Society for Technology in Education. 2014.

20. Claro M., Salinas Á., Cabello-Hutt T., San Martín E., Preiss D. D., Valenzuela S., \& Jara I. Teaching in a Digital Environment (TIDE): Defining and measuring teachers' capacity to develop students' digital information and communication skills. Computers \& Education. 2018. № 121. P. 162-174.

21. Ferreira V. G., Canedo E. D. Design sprint in classroom: exploring new active learning tools for project-based learning approach. Journal of Ambient Intelligence and Humanized Computing. 2020. № 11(3). P. 1191-1212.

22. Gómez-Pablos V. B., del Pozo M. M., Muñoz-Repiso A. G. V. Project-based learning (PBL) through the incorporation of digital technologies: An evaluation based on the experience of serving teachers. Computers in Human Behavior. 2017. № 68. P. 501512.

23. Наливайко O. Stop motion проекти як засіб формування цифрової компететності здобувача освіти. Наукові записки кафедри педагогіки. 2019. №45. С. 13-20. https://doi.org/10.26565/2074-8167-2019-45-02

\title{
MODEL OF STUDENTS' PROJECT ACTIVITY IN THE DIGITAL SPACE ON THE EXAMPLE OF DISCIPLINES OF THE PEDAGOGICAL CYCLE
}

\author{
Oleksii Nalyvaiko \\ Ph.D. in Pedagogy, Associate Professor of Pedagogy Department \\ V. N. Karazin Kharkiv National University, Kharkiv, Ukraine \\ nalyvaiko@karazin.ua \\ ORCID: 0000-0002-7094-1047
}

\begin{abstract}
The article presents a model of project activities of applicants for higher education in the context of distance-digital learning using the example of disciplines of the pedagogical training cycle. The analysis of the scientific sources devoted to various aspects of project activity and especially in digital educational space is carried out. The theoretical provisions of the project activities in the digital space are described and the tasks that applicants can perform within this activity are presented. The process of implementation of project activities in the conditions of forced distance learning is highlighted on the example of 2 nd year students of the School of Foreign Languages of V. N. Karazin Kharkiv National University in the 2019/2020 academic year, and attention is focused on the stages of creating and supporting this activity by a lecturer and a student. These stages include: preparatory (communication between applicants and the teacher), operational (project creation), correction (making changes and additions) and final (public defense and registration of the results). The discussion section reveals the prospects and risks of implementing project activities in the digital learning space. The conclusions provide recommendations for the effective organization of project activities in the digital learning space on the example of disciplines of the pedagogical cycle of training: previous preparatory work of the teacher to clarify the requirements for studying the course and organizing project activities (the emphasis here is on group monitors due to the large number of students: an average of 230 people); bright presentation of requirements and previous achievements in creating creative works (projects); defining a clear sequence of actions of this process; explanation of the sequence of actions and communication between the participants of the process teacher-student, teacher-group of students, student-student; support for feedback in consultations, in messengers (with an emphasis on convenience for all parties); current verification of the obtained results, i.e. support and correction of creative works with obligatory explanation of problematic moments for applicants; organization of public defenses of creative works (projects) on proven digital communication platforms; adherence to the principles of academic integrity in the context of distance digital learning through verification of works in generally recognized digital information verification programs; allocation of time for separate consultations for research projects as such,
\end{abstract}


which require special attention due to their complexity; the use of cloud services for recording the results of the progress of applicants and the like.

Keywords: teacher, distance learning, project activity, students, creative projects, digital learning tools.

\section{REFERENCES (TRANSLATED AND TRANSLITERATED)}

1. Nalyvaiko, O., Adzhva, D., \& Sarhsian, E. (2020). Distance Education in V.N Karazin Kharkiv National University in 2030, Students' View. Electronic Scientific Professional Journal "Open Educational e-Environment of Modern University", (9), 79-94. https://doi.org/10.28925/2414-0325.2020.9.7

2. Nalyvaiko, O., Kalistova, O., \& Poliakov, D. (2020). Compliance Academic Integrity Learning Achievements of Educational Applicants in the Process of Distance Learning. Educological Discourse, 31(4), 143-162. https://doi.org/10.28925/2312-5829.2020.4.10 (in Ukrainian)

3. Barron, B. J., Schwartz, D. L., Vye, N. J., Moore, A., Petrosino, A., Zech, L., \& Bransford, J. D. (1998). Doing with understanding: Lessons from research on problem-and project-based learning. Journal of the learning sciences, 7(3-4), 271-311.

4. Blumenfeld, P. C., Soloway, E., Marx, R. W., Krajcik, J. S., Guzdial, M., \& Palincsar, A. (1991). Motivating project-based learning: Sustaining the doing, supporting the learning. Educational psychologist, 26(3-4), 369-398.

5. Gary, K. (2015). "Project-Based Learning," in Computer, vol. 48, no. 9, pp. 98-100, doi: 10.1109/MC.2015.268.

6. Scarbrough, H., Swan, J., Laurent, S., Bresnen, M., Edelman, L., \& Newell, S. (2004). Project-based learning and the role of learning boundaries. Organization studies, 25(9), 1579-1600.

7. Bagheri, M., Ali, W. Z. W., Abdullah, M. C. B., \& Daud, S. M. (2013). Effects of project-based learning strategy on self-directed learning skills of educational technology students. Contemporary educational technology, 4(1), 15-29.

8. Barak, M., \& Raz, E. (2000). Hot-air balloons: Project-centered study as a bridge between science and technology education. Science Education, 84(1), 27-42.

9. Hung, C. M., Hwang, G. J., \& Huang, I. (2012). A project-based digital storytelling approach for improving students' learning motivation, problem-solving competence and learning achievement. Journal of Educational Technology \& Society, 15(4), 368379.

10. Lee, H. J. (2009, October). Peer evaluation in blended team project-based learning; what do students find important?. In E-Learn: World Conference on E-Learning in Corporate, Government, Healthcare, and Higher Education (pp. 2838-2842). Association for the Advancement of Computing in Education (AACE).

11. Zhernovnykova, O. A., Peretiaha, L. Y., Kovtun, A. V., Korduban, M. V., Nalyvaiko, O. O., \& Nalyvaiko, N. A. (2020). The Technology of Prospective Teachers' Digital Competence Formation by Means of Gamification. Information Technologies and Learning Tools, 75(1), 170-185. https://doi.org/10.33407/itlt.v75i1.3036 (in Ukrainian)

12. Amhag, L., Hellström, L., \& Stigmar, M. (2019). Teacher educators' use of digital tools and needs for digital competence in higher education. Journal of Digital Learning in Teacher Education, 35(4), 203-220.

13. Ardaiz-Villanueva, O., Nicuesa-Chacón, X., Brene-Artazcoz, O., de Acedo Lizarraga, M. L. S., \& de Acedo Baquedano, M. T. S. (2011). Evaluation of computer tools for 
idea generation and team formation in project-based learning. Computers \& Education, 56(3), 700-711.

14. Moursund, D. (1999). Project-based learning using information technology. Eugene, OR: International Society for Technology in Education. 157 p.

15. Bell, S. (2010). Project-based learning for the 21st century: Skills for the future. The clearing house, 83(2), 39-43.

16. Miglino, O., \& Walker, R. (2010). Teaching to teach with technology-a project to encourage take-up of advanced technology in education. Procedia-Social and Behavioral Sciences, 2(2), 2492-2496. https://doi.org/10.1016/j.sbspro.2010.03.359

17. Raat, J. H., \& de Vries, M. (1987). Technology in education: Research and development in the project 'Physics and Technology'. International Journal of Science Education, 9(2), 159-168.

18. Barreda, S. V. (2016). Analysis of project based learning in a digital environment at a networked high school. JETT, (7), 27-49.

19. Boss, S., \& Krauss, J. (2014). Reinventing project-based learning: Your field guide to real-world projects in the digital age. International Society for Technology in Education.

20. Claro, M., Salinas, Á., Cabello-Hutt, T., San Martín, E., Preiss, D. D., Valenzuela, S., \& Jara, I. (2018). Teaching in a Digital Environment (TIDE): Defining and measuring teachers' capacity to develop students' digital information and communication skills. Computers \& Education, 121, 162-174.

21. Ferreira, V. G., \& Canedo, E. D. (2020). Design sprint in classroom: exploring new active learning tools for project-based learning approach. Journal of Ambient Intelligence and Humanized Computing, 11(3), 1191-1212.

22. Gómez-Pablos, V. B., del Pozo, M. M., \& Muñoz-Repiso, A. G. V. (2017). Projectbased learning (PBL) through the incorporation of digital technologies: An evaluation based on the experience of serving teachers. Computers in Human Behavior, 68, 501512.

23. Nalyvaiko, O. (2019). Stop motion projects as a means of the formation students digital competence. Scientific Notes of the Pedagogical Department, 1(45), 13-20. https://doi.org/10.26565/2074-8167-2019-45-02 (in Ukrainian) 